Sri Iriantini, Vina Febriani, Toni Heryadi: Kesalahan Penganalisisan Kalimat Pasif dari...

\title{
KESALAHAN PENGANALISISAN KALIMAT PASIF DARI BAHASA JEPANG KE DALAM BAHASA INDONESIA
}

\author{
The Error Analysis of Passive Sentence From Japanese Into Indonesian \\ Sri Iriantini ${ }^{1}$, Vina Febriani Setiawan ${ }^{2}$, dan Toni Heryadi ${ }^{3}$ \\ ${ }^{1}$ Program Studi Sastra Jepang, Universitas Kristen Maranatha \\ Jalan Prof. drg. Surya Sumantri No. 65 Bandung \\ iriantinisri3@gmail.com, sri.iriantini@lang.maranatha.edu \\ ${ }^{2}$ Program Studi Sastra Jepang, Universitas Kristen Maranatha \\ Jalan Prof. drg. Surya Sumantri No.65 Bandung \\ vinafsetiawan@gmail.com \\ ${ }^{3}$ Balai Bahasa Provinsi Jawa Barat \\ Jalan Sumbawa Nomor 11, Bandung \\ toniheryadi7@gmail.com
}

Naskah masuk: 21 September 2020, disetujui: 15 Desember 2020, revisi akhir: 22 Desember 2020

\begin{abstract}
Abstrak
Penelitian ini mendeskripsikan perbedaan antara kalimat pasif dalam dua Bahasa, yaitu bahasa Indonesia dan Jepang. Kalimat pasif bahasa Jepang dapat ditunjukkan dengan verba benefaktif yarimorai yang dilekatkan pada verba inti untuk makna benefaktif, sedangkan dalam kalimat pasif bahasa Indonesia ditandai dengan prefiks di-, ter- dan ke-an. Verba benefaktif dalam bahasa Indonesia bukan kalimat pasif, melainkan kalimat aktif. Perbedaan itu sering membuat pembelajar bahasa Jepang melakukan kesalahan ketika pembelajar mengaplikasikan kalimat pasif bahasa Jepang. Tujuan penelitian ini adalah untuk mendeskripsikan kesalahan analisis pembelajar bahasa Jepang dalam mengubah kalimat pasif bahasa Jepang ke dalam Bahasa Indonesia. Metode penelitian yang diterapkan adalah metode deskriptif kualitatif, sedangkan teknik penelitian adalah studi kepustakaan dan metode kajiannya adalah kajian distribusional. Hasil penelitian ini adalah prefiks di- yang merupakan salah satu penanda pasif dalam bahasa Indonesia jika diungkapkan ke dalam bahasa Jepang tidak selalu bisa dipadankan dengan bentuk pasif reru/rareru sehingga hal ini menjadi kendala bagi pembelajar bahasa Jepang yang berbahasa ibu bahasa Indonesia.
\end{abstract}

Kata kunci: kalimat pasif Indonesia-Jepang, kalimat benefaktif Jepang, kesalahan analisis

\begin{abstract}
This study describes the difference between passive sentences in two languages, namely Indonesian and Japanese. Japanese passive sentences can be indicated by the benefactive verb yarimorai which is attached to the core verb for the benefactive meaning, while in Indonesian passive sentences it is marked with the prefix di-, ter-and ke-an. Benefactive verbs in Indonesian are not passive sentences, but active sentences. This difference often makes Japanese learners make mistakes when learners apply Japanese passive sentences. The purpose of this study was to describe the mistakes of Japanese learners in confirming Japanese sentences. The research method applied is descriptive qualitative method, while the research technique is literature study and the method of study is distributional studies. The result of this research is that the prefix di- which is one of the passive markers in Indonesian when expressed in Japanese cannot always be matched with the passive form reru / rareru so this becomes an obstacle for Japanese learners who speak Indonesian as their mother tongue.
\end{abstract} Keywords: Indonesian-Japanese passive sentences, Japanese benefactive sentences, error analysis 
Sri Iriantini, Vina Febriani, Toni Heryadi: Kesalahan Penganalisisan Kalimat Pasif dari...

\section{Pendahuluan}

Struktur kalimat pasif bersifat universal sehingga setiap bahasa pasti mempunyai struktur kalimat pasif. Namun, struktur atau bentuk pasif suatu bahasa akan memiliki keunikan atau perbedaan khusus antara bahasa yang satu dengan bahasa lainnya. Kalimat pasif bahasa Jepang memiliki keunikan tersendiri dibandingkan dengan kalimat pasif bahasa Indonesia.

Alwi, dkk (1998:336-337) mengungkapkan bahwa kalimat pasif adalah kalimat yang subjeknya dikenai suatu perbuatan atau tindakan atau aktivitas atau berperan sebagai sasaran. Kalimat pasif ini merupakan transformasi dari kalimat aktif, yaitu subjek berperan sebagai pelaku. Perhatikan contoh kalimat sebagai berikut.

1. Bola itu ditendang oleh Ali sekencangkencangnya.

Subjek pada kalimat 1 tersebut adalah bola, predikatnya adalah verba yang menggunakan imbuhan di- (ditendang), dan penendang atau pelakunya yang terletak setelah predikat adalah Ali. Ciri kalimat pasif dalam contoh kalimat tersebut, yaitu kata kerja yang menggunakan awalan di-. Pemasifan seperti ini umumnya digunakan jika subjek kalimat aktif berupa nomina atau frasa nominal (Alwi dkk, 1998: 346).

Selanjutnya, Alwi dkk (1998) mengemukakan bahwa selain dengan imbuhan di-, dalam bahasa Indonesia, imbuhan ter-pun dapat menunjukkan kepasifan yang bermakna 'ketaksengajaan', 'kekodratan', atau 'sesuatu yang harus demikian keadaannya'. Perhatikan contoh kalimat berikut.

2. Gunung Tangkuban Perahu terletak di Bandung, Jawa Barat.

3. Kaki saya terinjak (oleh) orang berbaju merah itu tadi.

Bentuk pasif dalam kalimat 2 ditunjukkan dengan kata terletak, yang bermakna 'kekodratan' dari keberadaan sebuah gunung yaitu gunung Tangkuban Perahu, sementara pelaku di sini tidak ada. Selanjutnya untuk kalimat pasif 3, bentuk pasif ditunjukkan dengan kata terinjak dari verba dasar injak dan penambahan prefiks ter-. Makna pasif dalam kalimat ini merupakan makna 'ketidaksengajaan' yang dilakukan oleh seseorang yang terletak setelah verba pasif terinjak, yaitu orang itu yang boleh disertai kata 'oleh' atau tidak karena walaupun tidak menggunakan oleh makna pelaku masih berterima (dapat dipahami). Untuk kalimat 3 ini, kata terinjak diubah menjadi diinjak yang menggunakan imbuhan pasif di-, maka maknanya pun akan berubah, tidak lagi 'ketidaksengajaan,' tetapi sebaliknya adanya 'kesengajaan' yang dilakukan oleh 'orang yang berbaju merah'.

Selain itu, masih ada bentuk kalimat pasif lain dalam bahasa Indonesia, yaitu kalimat pasif yang bermakna adversatif, seperti pada contoh kalimat berikut.

\section{Partai kita kemasukan unsur kiri.}

Contoh kalimat 4 tersebut menggunakan imbuhan ke-an pada kata kemasukan yang bermakna adversatif, yaitu makna yang tidak menyenangkan untuk subjek, yaitu partai kita, dengan masuknya unsur kiri yang bermakna asosiatif merujuk pada golongan/grup yang tidak sehaluan dengan subjek.

Dengan demikian, dapat dipahami bahwa bentuk pasif dalam bahasa Indonesia dapat diamati dari penggunaan imbuhan yang melekat pada verba yang mengisi fungsi predikat dalam suatu kalimat. Dari hal tersebut dapat dipahami bahwa kalimat pasif dalam bahasa Indonesia ditandai dengan imbuhan di-, ter-, dan ke-an.

Seperti halnya dalam bahasa Indonesia, bahasa Jepang pun terdapat kalimat pasif. Kalimat pasif bahasa Jepang secara struktur berbeda dengan kalimat pasif bahasa Indonesia. Perbedaan kalimat pasif itu adalah penggunaan jodoshi rareru yang dilekatkan pada verba inti yang mengisi fungsi predikat dalam suatu kalimat. Pelekatan jodoshi rareru penanda bentuk pasif ini disesuaikan dengan jenis verba tersebut yang terdiri dari tiga, yaitu godan doushi (verba grup 1), ichidan doushi (verba grup 2), dan henkaku doushi (verba grup 3). Perhatikan contoh kalimat berikut ini.

5. 妹 は 犬 に かまれた。(NBJ: 634)

Imouto wa inu ni kamareta 
Sri Iriantini, Vina Febriani, Toni Heryadi: Kesalahan Penganalisisan Kalimat Pasif dari...

Adik pr Nom anjing oleh gigit di (lampau)

'Adik digigit (oleh) anjing'.

Contoh kalimat 5 adalah kalimat pasif yang merupakan transformasi dari kalimat aktif, yaitu dari kalimat inu wa imouto $o$ kamimashita. Verba kamu yang menjadi predikat dalam kalimat 5 tersebut diubah ke dalam bentuk pasif dengan melekatkan jodoushi reru/rareru pada verba kamu (verba grup 1) menjadi kamareru dalam bentuk lampau kamareta. Selanjutnya, objek penderita imouto dipindahkan menjadi subjek yang diletakkan di awal kalimat dan penggigit diletakkan di tengah dengan pemarkah ni. Kalimat pasif seperti ini memiliki proses yang sama dengan kalimat pasif yang ada dalam bahasa Indonesia. Oleh karena itu, kalimat adik digigit (oleh) anjing dapat diterjemahkan ke dalam bahasa Jepang dengan menggunakan bentuk pasif reru/rareru.

6. a.私 は 今朝、電車 の 中 で 足を踏まれた。

Watashi wa kesa, densha no naka de ashi o fumareta.

Saya Top tadi pagi kereta Gen dalam di kaki Acc injak di (lampau)

'Kaki saya tadi pagi diinjak/terinjak (oleh seseorang) di dalam kereta'. (NHJ : 634)

Pada contoh kalimat 6, kalimat pasif ditunjukkan dengan penggunaan verba fumu 'menginjak' dalam bentuk pasif fumareta 'diinjak' dengan melekatkan jodoushi rareru pada verba fumu tersebut menjadi fumareru dalam bentuk lampau fumareta. Subjek penderita dalam hal ini hanashite 'penutur', diinjak kakinya oleh seseorang yang tidak hadir dalam kalimat, ketika dia berada di dalam kereta. Kalimat pasif bahasa Jepang ini seolah-olah sama dengan jenis kalimat pasif dalam bahasa Indonesia. Akan tetapi, jika diperhatikan baik-baik, objek penderita yaitu ashi 'kaki' dalam kalimat pasif bahasa Jepang diletakkan berurutan dengan verba pasif dan dimarkahi dengan joshi 'kata bantu/pemarkah' 0 . Sementara itu, jika diterjemahkan ke dalam bahasa Indonesia, kalimat pasif bahasa Jepang itu akan menjadi kalimat sebagai berikut.
'Kaki saya tadi pagi terinjak/diinjak di dalam kereta',

6.*b. 私の足 は今朝、電車の 中 で 踏まれた。

*(watashi no ashi wa kesa densha no naka de fumareta).

Jika menerjemahkan dari bahasa Jepang ke bahasa Indonesia, pembelajar sudah banyak yang benar dalam menerjemahkannya. Akan tetapi, jika sebaliknya pembelajar menerjemahkan dari bahasa Indonesia 'Kaki saya tadi pagi terinjak/diinjak (oleh seseorang) di dalam kereta' ke dalam bahasa Jepang, pembelajar masih banyak yang melakukan kesalahan/keliru menjadi seperti kalimat $6 \mathrm{~b}$ ini. Oleh sebab itu, pemahaman bentuk dan struktur kalimat pasif dalam bahasa Jepang sangat diperlukan untuk menghindari kesalahan seperti ini.

Selanjutnya perhatikan contoh kalimat berikut ini:

\section{7. 忙しい 時に 客にに来られて、 \\ 仕事 が できなかった。 \\ Isogashii toki ni kyaku ni korarete, shigoto ga dekinakatta \\ Sibuk waktu di tamu oleh datang di, pekerjaan Nom bisa tidak (lampau) \\ 'Didatangi oleh tamu di saat sibuk, jadi tidak bisa bekerja'. (NBJ : 633)}

Kalimat pasif pada contoh 7 ini merupakan kansetsu ukemi 'pasif taklangsung' yang bermakna adversatif. Kalimat pasif ini menggunakan verba kuru dalam bentuk pasif sambung korarete (verba grup 3), yaitu dengan pelesapan subjek penderita hanashite 'penutur'.

Makna keseluruhannya adalah penutur didatangi seorang tamu saat dia bekerja sehingga dia tidak bisa bekerja.

Di dalam bahasa Indonesia pun terdapat bentuk pasif yang menggunakan imbuhan di-kan yang bermakna benefaktif atau peruntung seperti kalimat pasif Bahasa Jepang. Perhatikan contoh kalimat berikut.

8. a.Karangan saya dibetulkan/dikoreksi oleh Pak Ali. 
Sri Iriantini, Vina Febriani, Toni Heryadi: Kesalahan Penganalisisan Kalimat Pasif dari...

Pada contoh kalimat pasif 8 tersebut, digunakan imbuhan penanda pasif di-kan yang merupakan bentuk pasif dari imbuhan aktif me-kan yang melekat pada verba beli. Namun, jika kalimat pasif dalam bahasa Indonesia ini diterjemahkan ke dalam bahasa Jepang, kalimat pasif itu tidak bisa menggunakan bentuk pasif rareru, tetapi harus menggunakan verba yarimorai (hojodoushi) yang digabungkan dengan verba inti karena mengandung makna benefaktif, seperti berikut.

\section{8.b. Watashi wa Ali sensei ni sakubun o naoshitemoraimashita.}

${ }^{*}$ c. Watashi no sakubun wa Ali sensei ni naosaremashita. (X)

*d. Watashi wa Ali sensei ni sakubun o naosaremashita. (X)

Kalimat 8b adalah padanan yang paling tepat dari kalimat pasif dalam bahasa Indonesia 'dibetulkan/dikoreksi', tidak menggunakan bentuk pasif reru/rareru menjadi naosaremashita, seperti di kalimat 8c dan 8d. Pada kalimat 8c, verba sudah diubah ke dalam bentuk pasif, tetapi di dalam bahasa Jepang hal ini tidak berterima secara makna. Frase watashi no sakubun pun tidak tepat urutannya.untuk kalimat pasif bahasa Jepang. Sementara kesalahan pada kalimat 8d terjadi pada verba naosaremashita karena kalimat ini tidak berterima jika menggunakan bentuk pasif reru/rareru.

Dari contoh-contoh kalimat tersebut, dapat dipahami bahwa kalimat pasif dalam bahasa Indonesia dan bahasa Jepang memiliki beberapa perbedaan mendasar yang dapat menyulitkan pembelajar dari Indonesia dalam memahami, menerjemahkan, dan mengaplikasikannya.

Penelitian ini akan membahas perbedaan-perbedaan yang terdapat pada kalimat pasif bahasa Indonesia dan bahasa Jepang. Perbedaan itu terutama karena kalimat pasif dalam bahasa Indonesia yang bermakna benefaktif pun menggunakan imbuhan penanda pasif di-, sementara kalimat pasif dalam bahasa Jepang menggunakan verba yarimorai, lalu padanan terjemahan yang tepat untuk kalimat pasif dalam kedua bahasa. Dari penelitian ini, diharapkan pembelajar baha- sa Jepang dari Indonesia dapat memahami dengan baik kalimat pasif dalam bahasa Indonesia dan bahasa Jepang sehingga dapat menggunakannya dengan baik pula dalam pertuturan dan penerjemahan.

Berdasarkan alasan tersebut, penulis tertarik untuk meneliti kesalahan analisis pembelajar bahasa Jepang dari Indonesia dalam menentukan jenis kalimat pasif bahasa Jepang dan kesalahan dalam penerjemahan kalimat pasif bahasa Jepang.

Tujuan penelitian ini adalah untuk mengetahui kesalahan analisis pembelajar dalam menentukan jenis kalimat pasif dalam Bahasa Jepang dan Bahasa Indonesia. Selain itu, penelitian ini bertujuan untuk menganalisis kesalahan penerjemahan kalimat pasif bahasa Jepang ke dalam bahasa Indonesia.

Kerangka teori yang digunakan dalam penelitian ini di antaranya tentang kalimat pasif berprefiks $d i$ - dan $t e(R)$ - dalam bahasa Indonesia. Selain itu, digunakan pula kalimat pasif kanonis dan ergataif dalam bahasa Indonesia. Teori kalimat pasif bahasa Indonesia ini dijadikan sebagai pembanding dengan kalimat pasif bahasa Jepang. Selain itu, dipakai pula teori Serpih-Serpih Telaah Pasif Bahasa Indonesia, teori kekacauan berbahasa, Tata Bahasa Baku Bahasa Indonesia, dan Tata Bahasa Jepang, serta Linguistik Bahasa Jepang. Buku-buku berbahasa Jepang seperti Nihonggo Bunpou Nyuumon, Kinouteki Koubun ni Yuro NichiEigo Hikoku.

Penelitian serupa mengenai kalimat pasif bahasa Jepang ini pernah dilakukan oleh beberapa linguis. Sutedi (2016) meneliti Analisis Contrastif Kalimat Pasif Bahasa Jepang dan Indonesia. Dalam penelitiannya, The types of passive sentences that cannot be paired could lead the Japanese language learners in Indonesia to make errors in their use of these sentence types. Finally, it is necessary to perform follow-up efforts to organize the structure of Japanese passive sentence learning materials in Indonesia in order to revise the existing teaching materials (Sutedi, 2016). Lebih lanjut, Sutedi (2013) menjelaskan berdasarkan fungsi dan kategori kalimat pasif murni 
Sri Iriantini, Vina Febriani, Toni Heryadi: Kesalahan Penganalisisan Kalimat Pasif dari...

bahasa Jepang terbagi atas tiga jenis, yaitu tipe $A, B$, dan $C$, sedangkan berdasarkan peran sematisnya, kalimat pasif bahasa Jepang terdiri atas delapan tipe. Sutedi, (2004) mengkaji berbabagai permaslahan dalam perubahan kalimat pasif berbahasa Jepang. Semua penelitian Sutedi sangat bermanfaat untuk dijadikan sebagai kajian terdahulu.

Dewi, Nimashita, \& Isnaini (2017) meneliti penerjemahan kalimat pasif berbahasa Indonesia ke dalam bahasa Jepang. Penelitian ini merupakan kebalikan dari penelitian yang kami lakukan, yaitu penerjemahan kalimat pasif dari bahasa Jepang ke dalam bahasa Indonesia. Penelitian ini berfungsi untuk membandingkan dengan penelitian yang akan kami lakukan.

Desilawati \& Kasnaria, (2018) mengkaji kemampuan Siswa Kelas XI Jurusan Teknik Tenaga Jaringan Listrik dalam membuat kalimat pasif bahasa Indonesia. Penelitian ini akan dipadukan dengan penelitain Heryadi (1999) tentang "Perbandingan Kalimat Pasif Berprefiks di- dan te(R)dalam Bahas Indonesia". Dengan demikian, penulis akan menjadikan penelitian tersebut sebagai dasar kalimat pasif bahasa Indonesia.

Secara umum kalimat pasif merupakan hasil dari pemasifan dari kalimat aktif. Peran pelaku dalam kalimat pasif memiliki enam tipe, sedangkan pelaku dalam kalimat pasif berfungsi sebagai predikat, pelengkap, dan keterangan (Saidi, 2016). Fungsi predikat dalam kalimat pasif bahasa Jepang ditempati oleh verba transitif (Puspa, 2014).

Penelitian lain yang dapat menunjang penelitian ini adalah Kesalahan Penggunaan Kalimat Pasif Bahasa Jepang pada Mahasiswa Undip (Novikasari, 2016). Penelitian ini hampir memiliki kesamaan dengan yang penulis teliti. Akan tetapi, penulis memiliki posisi pada perubahan kalimat pasif dari bahasa Jepang ke dalam kalimat pasif bahasa Indonesia.

\section{METODE PENELITIAN}

Metode yang digunakan dalam penelitian ini adalah metode kualitatif dengan penyajian data yang deskriptif. Metode kualitatif digunakan karena penelitian ini merupakan penelitian kualitatif yang secara fundamental bergantung pada pengamatan manusia dalam kawasannya sendiri dan berhubungan dengan masyarakat tersebut melalui bahasanya serta peristilahan. Selanjutnya, pengamatan tersebut dideskripsikan sesuai dengan data alami yang didapatkan.

Teknik penelitian yang dilakukan adalah studi kepustakaan dengan mencari hal-hal yang dikaitkan dengan gejala-gejala kebahasaan yang muncul yang mengakibatkan timbulnya suatu pertanyaan yang dapat dijadikan suatu permasalahan. Selanjutnya, dengan metode kajian distribusional, data dikaji sesuai dengan struktur kalimat pasif yang digunakannya dengan alat penentu unsur bahasa itu sendiri. Dari hasil mengontrastifkan kalimat pasif bahasa Jepang dengan bahasa Indonesia, akan dideskripsikan persamaan dan perbedaan antara kedua kalimat pasif tersebut dengan memadankannya.

Pengumpulan data diambil dari beberapa cerita rakyat Jepang, yaitu cerita 頭に柿の木Atama ni Kaki no Ki, 天人にようぼう、Tennin Nyoubou，わらしべ長者 Warashibe Chouja，分乏神Bimbougami， dan つぶむすこTsubumusuko. Data yang telah terkumpul melalui metode teknik catat dikaji dengan metode kajian distribusional dan dianalisis dengan teknik dasar, yaitu teknik Pilah Unsur Penentu (PUP).

Langkah-langkah kesalahan analisis pemasifan bahasa Jepang adalah sebagai berikut.

a) Mengumpulkan data: berasal dari tugas mahasiswa Jurusan Bahasa Jepang sebanyak 156 orang di Universitas Maranata

b) Mengklasifikasikan kesalahan analisis kalimat pasif

c) Memperingkatkan kesalahan analisis: mengurutkan kesalahan dan penyebab kesalahan

d) Menjelaskan kesalahan: menjelaskan dan memberikan contoh yang benar.

e) Mengoreksi kesalahan: memperbaiki kesalahan analisis dan mengevaluasi pengajaran.

Sumber data primer penelitian ini dari tugas-tugas mahasiswa jurusan Bahasa Jepang semester 3 sebanyak 156 orang, 
Sri Iriantini, Vina Febriani, Toni Heryadi: Kesalahan Penganalisisan Kalimat Pasif dari...

Adapun data sekunder penelitian ini berasal dari penelitian terdahulu yang menjadi bahan pertimbangan dalam penelitian.

Lokasi penelitian dilaksanakan di kampus Universitas Maranata, Jalan Surya Sumantri No. 65, Sukajadi, Bandung.

\section{HASIL DAN PEMBAHASAN}

Pada bagian pembahasan ini, dianalisis kalimat pasif dalam bahasa Indonesia dan kalimat pasif dalam bahasa Jepang lalu dikontrastifkan untuk diketahui persamaan dan perbedaannya. Selanjutnya, data hasil kontrastif dideskripsikan sesuai dengan fenomena data yang ditemukan dari berbagai cerita rakyat dan cerita anakanak. Data kalimat pasif bahasa Jepang diambil dari buku Nihon no Mukashibanashi yang berisi berbagai cerita rakyat di dalamnya, dan data kalimat pasif bahasa Indonesia pun diambil dari buku cerita anakanak Indonesia. Selain itu, digunakan pula data buatan yang berasal dari penutur orang Jepang sebagai data pendukung.

\subsection{Kontrastif Kalimat Pasif Bahasa Indonesia dan Jepang \\ 3.1.1 Kalimat Pasif Bahasa Indo- nesia}

(1) a.Mobil ayah dibeli temannya. (DB) kuruma chichi kawareru tomodachi chichi no

Data (1) a. di atas menggunakan bentuk pasif di- yang terdapat pada kata dibeli. Sasaran atau objek pasif pada kalimat tersebut adalah mobil kepunyaan ayah dan pelaku atau pembeli mobil tersebut adalah teman (ayah). Kalimat di atas biasa diungkapkan oleh orang Indonesia. Apabila kita melihat strukturnya, kalimat tersebut merupakan kalimat pasif. Akan tetapi, jika kalimat (1) ini diungkapkan dalam bahasa Jepang, kalimat itu tidak alami dan tidak akan berterima jika menggunakan bentuk pasif seperti itu.

*(1)b. Chichi no kuruma wa tomodachi ni kawareta. (X) dibeli

Ayah Pos mobil Top teman oleh

Bentuk verba pasif bahasa Indonesia dibeli diubah ke dalam bahasa Jepang dengan verba beli kau dan diubah ke dalam bentuk pasif lampau kawareta. Namun, kalimat (1)b. tidak berterima dalam bahasa Jepang, mereka akan menggunakan bentuk kau 'beli' dalam kalimat aktif dan tidak dalam bentuk pasif kawareru, seperti dalam kalimat berikut.

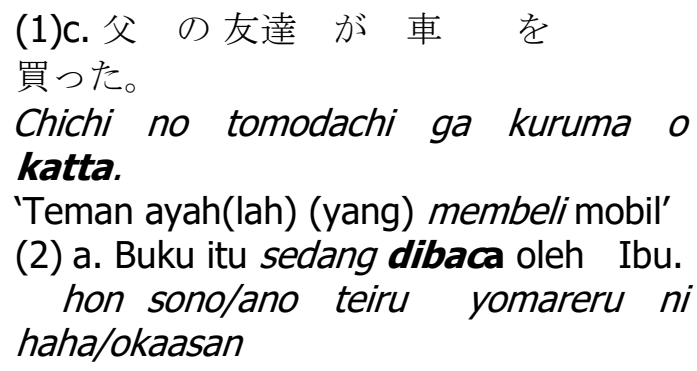
hon sono/ano teiru yomareru ni haha/okaasan

Pada kalimat (2) a. di atas digunakan bentuk pasif sedang dibaca yang masih menggunakan imbuhan penanda pasif bahasa Indonesia di-. Kalimat seperti ini lazim diucapkan oleh orang Indonesia untuk menyatakan bahwa ada sebuah buku tertentu yang memang sedang dibaca oleh Ibu. Akan tetapi, jika kalimat ini diubah ke dalam bahasa Jepang dengan struktur kalimat pasif bahasa Jepang yang menggunakan bentuk pasif reru/rareru, hal itu akan terasa janggal dan tidak dapat dipahami dengan baik oleh orang Jepang.

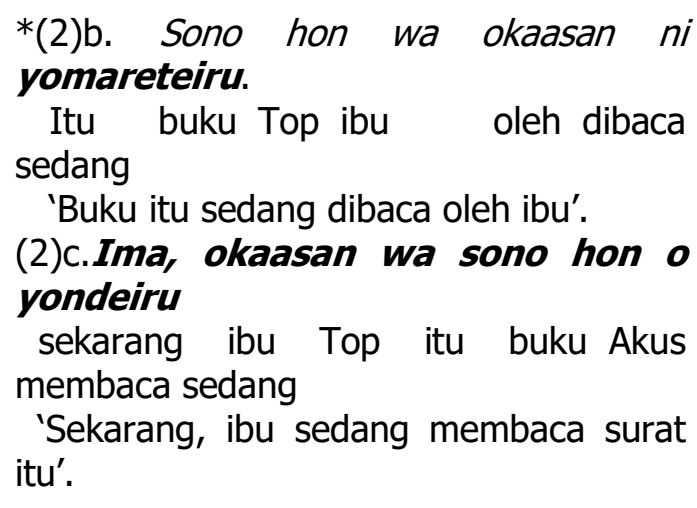

Kalimat pada data (1), data (2) pun akan terasa alami, dapat dipahami, dan makna akan tersampaikan dengan baik pada orang Jepang jika menggunakan verba beli dalam bentuk aktif progresif yondeiru 'sedang membaca', dan ibu 'okaasar' dijadikan subjek kalimat yang dimarkahi dengan kata bantu wa, seperti pada kalimat (2)c. 
Sri Iriantini, Vina Febriani, Toni Heryadi: Kesalahan Penganalisisan Kalimat Pasif dari...

(3) a. Ketika sedang mendengarkan berita tentang corona, televisinya dimatikan oleh adik saya.

Pada kalimat (3)a ini terdapat bentuk pasif dimatikan yang jika diterjemahkan ke dalam bahasa Jepang menjadi kesareta 消された. Untuk kalimat (3)a pun sama dengan data sebelumnya tidak bisa menggunakan kesareta karena jika menggunakan kesareta, seolah-olah televisi merupakan benda hidup yang mempunyai perasaan. Jadi, kalimat (3)a ini jika diubah ke dalam bahasa Jepang menjadi:

(3)b.コ口ナに関するニュースを聴いているとき、 私の弟はテレビを消した。

Korona ni kansuru nyuusu wo kiiteiru toki, watashi no otouto wa terebi o keshita.

Kalimat (3)b ini menggunakan verba aktif kesu 'mematikan' dalam bentuk lampau keshita, objek langsung nomina terebi, dan subjek pelaku yaitu watashi no otouto (adik laki-laki).

(4) a.Kamar itu dibersihkan oleh office boy tadi pagi.

$$
\text { Heya sono soujisareta ni }
$$$$
\text { office boy kesa }
$$

Kalimat (4)a ini yang menggunakan bentuk pasif di-kan pada kata dibersihkan dalam bahasa Jepang-nya pun tidak bisa menggunakan bentuk pasif reru/rareru seperti pada kalimat (4)b karena di sini ada pihak yang berbaik hati melakukan aktivitas membersihkan, dan ada pihak yang diuntungkannya juga (peruntung), yaitu orang yang mempunyai kamar. Oleh karena itu, dalam bahasa Jepang harus menggunakan bentuk benefaktif yang menggunakan verba yarimorai, seperti kalimat (4)c berikut ini:

$$
\begin{aligned}
& \text { *(4)b. Sono heya wa kesa } \\
& \text { office boy ni souji sareta. } \\
& \text { Itu kamar Top tadi pagi office } \\
& \text { boy oleh disapu/dibersihkan } \\
& \text { 'Kamar itu dibersihkan oleh office boy } \\
& \text { tadi pagi' (X) } \\
& \text { (4)c. Office boy ga kesa sono } \\
& \text { heya o souji shitekureta. }
\end{aligned}
$$

Office boy Nom tadi pagi itu kamar Akus membersihkan

'Office boy (lah) (yang) membersihkan kamar itu tadi pagi'.

Kalimat (4)b tidak lazim digunakan dalam bahasa Jepang dan maksud kalimat tidak akan dipahami dengan baik oleh orang Jepang. Dalam hal ini, kalimat (4)c-lah yang lazim dan alami digunakan oleh orang Jepang dan menggunakan salah satu verba benefaktif yaitu -tekureru yang melekat pada verba inti souji suru 'membersihkan'. Orang yang melakukan kebaikannya diletakkan di awal kalimat sebagai subjek dan penggunaan verba benefaktif kureru ini biasanya jika penerima kebaikan (peruntungnya) adalah pembicara yang merasa berterima kasih karena kamarnya telah dibersihkan.

(5) Putri Tangguk tinggal bersama suami dan ketujuh anaknya di daerah Jambi. Putri Tangguk memiliki sepetak sawah yang ditanami padi. Anehnya, setiap selesai panen, padinya selalu muncul dan siap untuk dipanen kembali. Bahkan, ketujuh lumbung Putri Tangguk hampir penuh untuk menampung hasil panennya.

Pada kalimat pasif pada data kalimat (5) tersebut terkandung dalam kalimat Anehnya, setiap selesai panen, padinya selalu muncul dan siap untuk dipanen kembali. Bentuk pasif dalam data bahasa Indonesia ini menggunakan awalan di- sebagai penanda pasif dalam bahasa Indonesia dan merupakan transformasi dari bentuk aktif memanen. Objek pasif dipanen dalam kalimat ini adalah padi dan pelaku pasifnya adalah Putri Tangguk dan keluarganya. Kata dipanen ini jika diungkapkan dengan bahasa Jepang dapat menggunakan bentuk pasif langsung yang sama maknanya dengan yang ada dalam bahasa Indonesia dan menggunakan bentuk pasif bahasa Jepang rareru bukan menggunakan verba benefaktif, yaitu shuukaku sareru 収穫される.

(6) Kemudian, mereka mendorong gerobak bersama-sama. Di tengah perjalanan, Putri Tangguk jatuh terpeleset. 
Sri Iriantini, Vina Febriani, Toni Heryadi: Kesalahan Penganalisisan Kalimat Pasif dari...

Kalimat pasif pada data (6) tersebut terkandung pada kalimat 'Di tengah perjalanan Putri Tangguk jatuh terpeleset. Kata terpeleset merupakan salah satu bentuk pasif dalam bahasa Indonesia yang menggunakan imbuhan ter- + kata dasar peleset. Akan tetapi, jika kata ini diterjemahkan ke dalam bahasa Jepang, kalimat tersebut tidak akan terasa alami jika menggunakan bentuk pasif dalam bahasa Jepang, yaitu reru/rareru, harus menggunakan struktur yang lain. Dengan demikian bentuk pasif ter- dalam bahasa Indonesia tidak selalu diterjemahkan ke dalam bahasa Jepang dengan bentuk pasif lagi. Pelaku pasif dalam hal ini tidak muncul dalam kalimat, tetapi objek pasif yang terletak di awal kalimat sebagai subjek hadir yaitu Putri Tangguk.

(7) Putri Tangguk mengambil padi dari gerobaknya. Kemudian, padi ditebar di jalan. Melihat perilaku ibunya, si anak sulung pun bertanya....

Bentuk pasif pada data (7) terdapat pada data kalimat 'Kemudian, padi ditebar di jalan'. Bentuk pasif ditebar yang menggunakan prefiks $d i$ - merupakan transformasi dari bentuk aktif menebar. Yang merupakan objek pasifnya, yaitu padi, dan pelaku pasifnya yaitu Putri Tangguk yang muncul pada kalimat sebelumnya.

Bentuk pasif ditebar jika diterjemahkan ke dalam bahasa Jepang bisa menggunakan bentuk pasif reru/rareru, sehingga bentuk pasif di- dalam bahasa Indonesia bisa dipadankan dengan salah satu bentuk pasif dalam bahasa Jepang, yaitu pasif langsung (chokusetsu ukemi).

(8) Putri Tangguk menangis seharian, bahkan, ia tidak mampu pulang dan menunggui sawahnya hingga ter-

tidur. Dalam mimpinya, Putri Tangguk didatangi segerombolan padi yang dapat berbicara.

Bentuk pasif pada data (8) di atas ada dua, yaitu yang menggunakan prefiks terpada kata tertidur dan prefiks di-i pada didatangi. Untuk bentuk pasif tertidur, sama halnya dengan kata terpeleset pada data sebelumnya jika diterjemahkan ke dalam bahasa Jepang tidak bisa menggunakan bentuk pasif lagi, yaitu dengan sufiks reru/rareru, tetapi akan terasa alami dengan bentuk -teshimau, menjadi 寝てしまった neteshimatta. Sementara untuk kata didatangi, dapat diterjemahkan dengan menggunakan bentuk pasif Jepang reru/rareru menjadi 来られて korarete. Pelaku pasif dalam kata tertidur adalah rasa cape setelah menangis seharian yang akhirnya membuat objek pasif Putri Tangguk mengantuk dan tertidur. Untuk bentuk pasif didatangi, pelaku pasifnya adalah segerombolan padi yang dapat berbicara yang mendatangi Putri Tangguk dalam mimpinya ketika tertidur saat itu. tertidur = neteshimatta didatangi $=$ korarete

(9) Tabanan merupakan salah satu kabupaten di provinsi Bali. Kabupaten ini terletak di bagian selatan pulau Bali. Daerah Tabanan didominasi oleh pegunungan dan pantai.

Bentuk pasif pada data (9) tersebut terdapat pada kata didominasi, yang merupakan transformasi dari bentuk aktif mendominasi. Pada kalimat pasif Daerah Tabanan didominasi oleh pegunungan dan pantai ini, pelaku pasifnya adalah pegunungan dan pantai, dan objek pasifnya adalah suatu daerah bernama Tabanan. Bentuk pasif seperti ini ada juga dalam bahasa Jepang yang termasuk ke dalam pasif langsung atau chokusetsu ukemi.

(10) Sepertiga wilayah Kabupaten Tabanan digunakan sebagai lahan Persawahan sehingga kabupaten inidikenal sebagai daerah agraris.

Data kalimat (10) mengandung dua bentuk pasif, yaitu pada kata digunakan dan dikenal. Keduanya menggunakan prefiks di- sebagai salah satu penanda bentuk pasif dalam bahasa Indonesia. Keduanya merupakan transformasi dari bentuk aktif menggunakan dan mengenal. Untuk kata digunakan, pelaku pasifnya tidak ada. Akan tetapi, objek kalimat pasifnya ada, yaitu suatu wilayah bernama Kabupaten Tabanan. Kemudian, kata dikenal pun sama, pelaku pasif tidak ada, dan objek pasif pun 
Sri Iriantini, Vina Febriani, Toni Heryadi: Kesalahan Penganalisisan Kalimat Pasif dari...

sama yaitu subjek kalimat tersebut Kabupaten Tabanan. Biasanya kalimat pasif seperti ini digunakan untuk mengungkapkan sebuah berita atau sebuah informasi kepada khalayak dan merupakan bentuk pasif yang lazim digunakan. Di dalam bahasa Jepang pun kalimat pasif seperti ini sering muncul.

(11) Si Pitung memutuskan untuk mengabdikan hidupnya pada rakyat jelata. Dia bertekad untuk mengambil kembali hak yang sudah dicuri oleh tuan tanah dan mengembalikannya kepada rakyat. Dia mengajak beberapa temannya untuk bergabung dengannya.

Data (11) di atas mengandung bentuk pasif pada kalimat Dia bertekad untuk mengambil kembali hak yang sudah dicuri oleh tuan tanah, dan mengembalikannya pada rakyat. Bentuk pasif terdapat pada kata dicuri sebagai transformasi dari bentuk aktif mencuri dengan pelaku pasifnya yang ditandai dengan kata oleh yaitu tuan tanah, dan objek pasifnya adalah hak (rakyat) yang terdapat pada kata yang terletak sebelum dicuri.

....hak yang -- sudah dicuri -- oleh tuan tanah...

objek pasif -- pasif lampau -- pelaku pasif Kalimat pasif seperti ini pun lazim ditemukan dalam bahasa Jepang, dan termasuk ke dalam pasif langsung atau chokusetsu ukemi, dan untuk penanda pelaku pasifnya menggunakan kata bantu ni (yotte).

(12) Kelakuan Si Pitung tidak disukai oleh tuan tanah dan juga pemerintah Belanda.

Bentuk pasif pada kalimat (12) terdapat pada kata disukai yang merupakan transformasi dari bentuk aktif menyukai dan didahului dengan kata tidak sebagai penanda negasi dalam bahasa Indonesia untuk verba. Objek pasif dalam kalimat ini adalah subjek yang terletak di awal kalimat yaitu Kelakuan Si Pitung, dan pelaku pasifnya adalah tuan tanah dan juga pemerintah yang didahului dengan kata oleh sebagai pennada pelaku pasif dalam suatu kalimat pasif. Bentuk pasif seperti ini pun lazim digunakan dalam bahasa Je- pang, dan dapat digolongkan ke dalam pasif langsung (chokusetsu ukemi).

(13) Sebagian hasil rampasan itu diberikan kepada pemerintah Belanda.

Data (13) tersebut mengandung bentuk pasif pada kata diberikan. Objek pasifnya adalah sebagian hasil rampasan perang. Pelaku pasifnya lesap tidak ada dalam kalimat ini dan objek dari pemberiannya atau pihak yang diberinya adalah pemerintah Belanda. Kata diberikan dalam kalimat seperti ini sering ditemukan dalam bahasa Indonesia. Akan tetapi, jika kalimat tersebut diungkapkan dalam bahasa Jepang, kata diberikan harus diganti dengan kata lain supaya maknanya tetap sama. Di dalam bahasa Jepang, bentuk pasif reru/rareru tidak bisa menggunakan kepada tetapi oleh. Penanda penerima objek benda atau jasa kepada biasanya menggunakan bentuk aktif memberikan yang dapat menggunakan verba ageru, kureru, ataeru, watasu, dan lainnya.

(14) Si Pitung cepat menguasai semua ilmu yang diajarkan oleh Haji Naipin.

Bentuk pasif pada data (14) ditunjukkan dengan kata diajarkan sebagai transformasi dari bentuk aktif mengajarkan. Kalimat pada data ini merupakan kalimat majemuk dan bentuk pasif diajarkan menerangkan kata ilmu yang diperoleh dari Haji Naipin. Objek pasif benda dalam kalimat ini adalah semua ilmu, sedangkan subjek pasifnya adalah Si Pitung, dan pelaku pasif atau orang yang mengajarkannya adalah Haji Naipin. Bentuk pasif diajarkan seperti ini jika diungkapkan dalam bahasa Jepang dapat menggunakan bentuk pasif reru/rareru sehingga menjadi 教えられた'oshierareta' seperti pada data yang ditemukan dari cerita rakyat Jepang, dan juga dapat menggunakan bentuk benefaktif 教えてもらつたoshietemoratta.

\subsubsection{Kalimat Pasif Bahasa Jepang}

Data kalimat pasif bahasa Jepang diambil dari buku cerita bahasa Jepang, dan terkumpul ada 18 data dari berbagai cerita rakyat Jepang, yaitu cerita 頭に柿の木 Atama ni Kaki no Ki, 天人にようぼう、Tennin 
Sri Iriantini, Vina Febriani, Toni Heryadi: Kesalahan Penganalisisan Kalimat Pasif dari...

Nyoubou，わらしべ長者 Warashibe Chouja， 貧乏神 Bimbougami, dan つぶむすこ Tsubumusuko. Dari data tersebut, yang menggunakan verba grup I atau godan doushi ada 14 data, yang menggunakan verba grup II atau ichidan doushi ada 2 data, dan yang menggunakan verba grup III atau henkaku doushi ada 2 data. Analisis akan dilakukan sesuai dengan pembagian verba secara morfologis.

\subsubsection{Verba Grup I Godan Doushi + Bentuk pasif reru/rareru}

(1)「「お、こりやみごとなかきが、いわぱいなっている。」

Oo, korya migoto na kaki ga, ippai natteiru

'Wow, buah kaki yang bagus ini, lebat sekali'

「なんと、頭に柿の木とは、めずらしい。」と、まわりの人にいわれ

"Nanto, atama ni kaki no ki to wa, mezurashii", mawarino hito ni iware

るものだから、三太郎も、だんだん面白くなってきました。(hal.8)

sekitar orang oleh

rumonodakara, Santarou mo, dandan omoshiroku natte kimashita

diomongin

'Oleh karena sering diomongin oleh orang sekitarnya seperti ini "hmm...

punya pohon kaki di atas kepala itu, sungguh bukan hal yang biasa", maka

Santarou pun semakin lama semakin menjadi pusat perhatian'.

Data tuturan di atas diambil dari cerita tentang seseorang bernama Santarou yang karena suatu alasan tertentu dia mempunyai pohon kesemek yang tumbuh di atas kepalanya. Pohon kesemek itu semakin lama semakin besar lalu berbuah lebat dan dijualnya ke pasar. Karena seseorang yang mempunyai pohon kaki berbuah lebat di atas kepala itu bukan sesuatu yang biasa terjadi, nama Santarou makin lama makin terkenal di desa tersebut. Buah kesemek dari kepala Santarou itu terjual habis sehingga penjual buah kesemek di pasar tersebut menjadi iri.
Pada data tersebut terdapat kalimat pasif まわりの人にいわれるものだから、

三太郎もだんだん面白くなつてきました。

Kepasifan dalam kalimat tersebut ditunjukkan oleh verba iwareru いわれる, yang merupakan bentukan dari verba grup I yaitu iu dilekati bentuk pasif rareru dan ditegaskan lagi dengan adanya joshi ni 'oleh' yang mengindikasikan adanya sesuatu yang dilakukan oleh seseorang kepada orang lain dan merupakan salah satu struktur kalimat pasif dalam bahasa Jepang.

まわりの人 に いわれる もの だから、三太郎 が。。。

Orang sekitar oleh diomongin orang karena Santarou ga

Pelaku pasif aktivitas

Pasien (korban $=$ orang yang

dikenai perbuatan pasif)

Kalimat pasif bahasa Jepang seperti ini ada juga dalam bahasa Indonesia, dan bisa diterjemahkan dengan kalimat pasif juga ke dalam bahasa Indonesia menjadi diomongin oleh orang-orang sekitar.

（2）きこりが もってかえってきたころもは、それはうつくしいもの

Kikori ga mottekaettekita koromo wa, sore wa utsukushii mono
Tukang kayu bawa pulang pakaian Top itu top cantik benda
でした。この の のもとはとても思われせん。 (hal. 18)
deshita. Kono yo no mono to wa totemo omowaremasen
ini dunia Pos benda Top sangat terpikirkan tidak
'Pakaian yang dibawa pulang tukang kayu itu, merupakan pakaian yang


Sri Iriantini, Vina Febriani, Toni Heryadi: Kesalahan Penganalisisan Kalimat Pasif dari...

sungguh cantik, tidak terpikir sama sekali sebagai pakaian yang berasal dari dunia ini'.

Tuturan tersebut diambil dari cerita Tennin Nyoubou, tentang seorang tukang kayu yang beruntung dapat memperistri seorang putri dari kayangan, setelah dia menyembunyikan pakaian putri tersebut ketika sedang mandi di danau tempat tukang kayu itu biasa menebang kayu. Pakaian yang dibawa pulang oleh tukang kayu itu merupakan pakaian yang sungguh indah, sampai tukang kayu itu merasa itu bukan berasal dari dunia tempat manusia tinggal, pasti dari dunia lain.

Kalimat pasif pada tuturan tersebut terdapat di bagian akhir tuturan, yaitu:

この 世 の もの とはとても思われません。
Kono yo no mono to wa totemo
omowaremasen

'Tidak terpikir sama sekali sebagai benda yang berasal dari dunia ini'

Pelaku pasif omowareru dalam kalimat ini adalah subjek yang telah disebutkan di awal tuturan, yaitu kikori 'tukang kayu', dan yang menjadi 'hal yang dipikirkan' adalah koromo 'pakaian' yang ditemukan oleh tukang kayu tersebut. Verba grup I omou dalam kalimat di atas dilekati bentuk pasif rareru menjadi omowareru dan menjadi penanda bahwa kalimat itu merupakan kalimat pasif dan termasuk ke dalam kalimat pasif langsung (直接受け身chokusetsu ukemi). Akan tetapi, jika diterjemahkan ke dalam bahasa Indonesia, lebih alami jika menggunakan bentuk pasif ter-verba dasar sehingga bukan dipikirkan tetapi menjadi terpikir.

（3）それから、一年。「おや、頭がむずむずする。」んんどは、

sorekara, ichinen, 'Oya, atama ga musumusu suru', kondo wa

kemudian, 1 tahun, 'eeh, kok kepala saya gerak-gerak ya', kali ini Top

きられ たかきの切り株から、もこもこと、きのこがはえてきま

kirareta kaki no kirikabu kara, mokomoko to, kinoko ga haetekima

dipotong kesemek akar dari secara perlahan jamur Nom tumbuh

した。「こや、よかった。」(hal. 12)

shita. 'korya, yokatta'.

'aaah, syukurlah'

'Satu tahun kemudian, 'eeh, kok kepala saya gerak-gerak ya', kali ini, dari akar pohon kesemek yang dipotong, secara perlahan tumbuhlah jamur. 'aah, syukurlah'.

Pada data kalimat (3) terdapat bentuk pasif yang ditunjukkan oleh verba kirareta, dari bentuk dasar kiru dilekati bentuk pasif rareru menjadi kirareru dalam bentuk lampau kirareta 'dipotong'. Merupakan salah satu bentuk pasif langsung yang menjelaskan nomina di depannya yaitu buah kaki 'kesemek'. Pelaku pasif dalam kalimat ini adalah seseorang yang memotong pohon kesemek yang tumbuh di kepala Santarou, dan objek pasifnya adalah pohon kesemek. Akan tetapi, di tempat dipotongnya pohon kesemek itu setahun kemudian tumbuhlah jamur, dan ini membuat Santarou gembira kembali. Bentu pasif kirareta dapat diterjemahkan ke dalam bahasa Indonesia dengan awalan di- juga sebagai penanda bentuk pasif dalam bahasa Indonesia dan sebagai transformasi dari bentuk aktif memotong.

\section{こんどは、切られたかきの切り株から、。。 kirareta kaki no kirikabu kara dipotong}

(4)「おつとと、と。」

Otto to, to 
Sri Iriantini, Vina Febriani, Toni Heryadi: Kesalahan Penganalisisan Kalimat Pasif dari...

足 をとられて、すってーんと、ころんでしまいました。そのとたん、

ashi wo torarete, sutte-nto, koronde shimaimashita. Sono totan,

kaki Akus disandung brukk terguling / terjatuh saat itu juga

バシャツと頭の 池 の水がこぼれて、からつぽになってしまいました。

bashatsu to atama no ike no mizu ga koborete, karappo ni natte shimaimashita.

pyaarr.....air kolam yang di kepala tumpah, sehingga menjadi kosong.

'Gubraak, kaki disandung dengan sengaja (oleh seseorang), bruukk terjatuh. Dan saat itu pula pyaar air kolam yang ada di kepala tumpah sehingga kolamnya menjadi kosong'. (hal. 16)

Data (4) di atas mengandung bentuk pasif yaitu ashi wo torarete yang dibentuk dari verba dasar toru 'ambil/sandung' dilekati bentuk pasif rareru menjadi torareru dilekati lagi bentuk sambung te menjadi torarete. Jenis pasif yang terdapat pada kalimat ini adalah chokusetsu ukemi (pasif langsung). Pelaku pasif dalam kalimat ini adalah seseorang yang tidak hadir dalam bacaan, dan objek pasifnya adalah seseorang yang bernama Santarou yang muncul dalam paragraf sebelumnya. Bacaan ini diambil dari cerita atama ni kaki no ki yang pelaku utamanya adalah Santarou. Kaki Santarou disandung dengan sengaja oleh seseorang yang merasa iri, karena kolam di atas kepalanya penuh dengan ikan, dan ikannya laku di pasaran sehingga penjual ikan yang lain merasa dirugikan.

Bentuk pasif ashi wo torarete jika diungkapkan dalam bahasa Indonesia bisa menggunakan bentuk pasif di- tetapi ashi atau kaki diletakkan sebelum kata disandung tidak sebagai objek seperti dalam kalimat data (4) di atas. Jadi, dalam bahasa Indonesia menjadi 'kakinya disandung (oleh seseorang dengan sengaja)'.

(5)きこりは、天女が教えてくれたように、三本だけ木をきり Kikori wa tenjou ga oshietekureta youni, sanbon dake ki wo kiri

Tukang kayu bidadari diajarkan seperti 3 batang hanya pohon Akus

たおしました。そして、切り株まくらに、ねていました。 taoshimashita, soshite, kirikabu makura ni, neteimashita.

menumbangkan, lalu, di pangkal pohon yang sudah ditebang, tidur

しばらくして、はつと、目をさますと、どうでしょう。 Shibaraku shite, hatto, me wo samasu to, doudeshou.

Tak lama kemudian, suuut, mata Akus membuka apakah yang terjadi?

千町歩の山～は たった一日できりひらかれていました。 (hal.30)

senchoubu no yama wa tatta ichinichide kirihirakareteimashita

seribu hektar gunung Top hanya satu hari terpotong seluruhnya

'Tukang kayu itu memotong hanya 3 pohon kayu saja, lalu pangkal pohon yang sudah ditebang itu dia jadikan bantal, dan tidur di atasnya. Tak lama kemudian, ketika dia membuka matanya, pohon-pohon di gunung seluas ribuan hektar tersebut dalam waktu sehari saja, sudah terpotong seluruhnya'.

Bentuk pasif pada data (5) di atas terdapat pada akhir tuturan yaitu kirihirakaremashita yang terbentuk dari verba dasar kirihiraku yang dilekati bentuk pasif rareru. Pelaku pasifnya adalah entah siapa yang membantu tukang kayu itu memotong seluruh pohon kayu di gunung tersebut. Objek pasifnya adalah pohonpohon kayu. Bentuk pasif kirihirakaremashita ini jika diungkapkan dalam bahasa Indonesia lebih tepat menggunakan prefiks penanda pasif ter- sehingga bila diterjemahkan menjadi 'terpotong'. 
Sri Iriantini, Vina Febriani, Toni Heryadi: Kesalahan Penganalisisan Kalimat Pasif dari...

\subsubsection{Verba Grup II Ichidan doushi + Bentuk Pasif reru/rareru}

(6) 夫はかえつてきたにようぼうに、賓乏神に教えられたことを

Otto wa kaettekita nyoubou ni, binbougami ni oshierareta koto wo

Suami Top pulang istri kepada Dewa kemiskinan oleh diajarkan hal Akus

はなしました。

hanashimashita

membicarakan

'Sang suami membicarakan hal yang diajarkan oleh Dewa Kemiskinan

kepada istrinya'.

Pada data kalimat (6) di atas terdapat bentuk pasif yang menggunakan verba grup II yaitu oshieru yang dilekati oleh bentuk pasif rareru dalam bentuk lampau menjadi oshierareta. Kalimat pasif binbougami ni oshierareta koto ini termasuk ke dalam bentuk pasif langsung (chokusetsu ukemi). Pelaku pasifnya yaitu binbougami 'dewa kemiskinan', yang dikenai perbuatan pasifnya yaitu subjek dalam hal ini adalah otto 'seorang suami'. Jadi, kalimat ini menjelaskan tentang adanya sepasang suami istri yang sedang berbincang dan suaminya membicarakan hal-hal yang telah diajarkan oleh dewa kemiskinan (terhadapnya) kepada istrinya.

Bentuk pasif 貣乏神におしえられたこと binbougami ni oshierareta koto jika diterjemahkan ke dalam bahasa Indonesia menggunakan prefiks di- lagi sebagai penanda pasif dalam bahasa Indonesia, menjadi 'hal yang diajarkan oleh dewa kemiskinan'.

\subsubsection{Verba Grup III Henkaku doushi + Bentuk Pasif reru/rareu \\ (7)「三太郎のおかげで、こつちは見むきもされない。」(hal. 15) \\ Santarou no okage de, kocchi wa mimuki mo sarenai \\ 'Berkat Santarou, sebelah sini, ditoleh pun tidak...dilakukan...'}

Bentuk pasif pada data kalimat (7) ini menggunakan verba grup III, yaitu suru dalam bentuk pasif negasi menjadi sarenai. Pelaku pasifnya dalam kalimat ini lesap. Akan tetapi, dari konteks kalimat dapat diketahui yaitu orang-orang di sekitar pembicara yang tidak menoleh sedikitpun kepada penjual salah satunya pembicara yang ada di sana setelah ada Santarou. Dengan demikian, pasien/pengalam dari perbuatan pasif dalam kalimat tersebut adalah orang-orang yang berada di sekitar sana yang ditunjukkan dengan kata kocchi. Kalimat pasif pada data ini termasuk ke dalam chokusetsu ukemi 'pasif langsung'.

Tabel 1: Kalimat Pasif dalam Bahasa Indonesia

\begin{tabular}{|c|l|l|}
\hline $\begin{array}{c}\text { Data } \\
\text { No. }\end{array}$ & \multicolumn{1}{|c|}{ Kalimat Pasif } & \multicolumn{1}{|c|}{ Ekspresi dalam bahasa Jepang } \\
\hline 1 & Mobil ayah dibeli temannya & $\begin{array}{l}\text { Chichi no tomodachi ga kuruma o katta 買った } \\
\text { (bentuk aktif verba kau 'membeli' }\end{array}$ \\
\hline 2 & Buku itu sedang dibaca oleh ibu. & $\begin{array}{l}\text { Ima okaasan wa sono hon o yondeiru } \\
\text { 読んでいる(bentuk aktif verba yomu 'membaca' } \\
\text { progresif teiru) }\end{array}$ \\
\hline 3 & $\ldots . .$, televisinya dimatikan adik saya. & $\begin{array}{l}\text {... Watashino otouto wa terebi o kesu } \\
\text { 消す(bentuk aktif verba kesu 'mematikan') }\end{array}$ \\
\hline
\end{tabular}


Sri Iriantini, Vina Febriani, Toni Heryadi: Kesalahan Penganalisisan Kalimat Pasif dari...

\begin{tabular}{|c|c|c|}
\hline 4 & $\begin{array}{l}\text { Kamar itu dibersihkan oleh office boy } \\
\text { tadi pagi. }\end{array}$ & $\begin{array}{l}\text { Office boy ga kesa sono heya o } \\
\text { soujishitekureta.掃除してくれた (verba } \\
\text { benefaktif kureru bukan pasif reru/rareru) }\end{array}$ \\
\hline 5 & ...siap untuk dipanen kembali & 収穫されるshuukakusareru \\
\hline 6 & ...Putri Tangguk jatuh terpeleset. & 滑らせたsuberaseta (bukan pasif) \\
\hline 7 & ....padi ditebardi jalan & 波及されるhakyuusareru \\
\hline 8 & $\begin{array}{l}\text {......menunggui sawahnya } \\
\text { hingga tertidur } \\
\text {.....Putri Tangguk didatangi } \\
\text { segerombolan padi }\end{array}$ & $\begin{array}{l}\text { 寝てしまつたneteshimatta (bukan pasif) } \\
\text { 来られるkorareru }\end{array}$ \\
\hline 9 & $\begin{array}{l}\text { Daerah Tabanan didominasi oleh } \\
\text { pegunungan dan pantai. }\end{array}$ & 支配されるshihaisareru \\
\hline 10 & 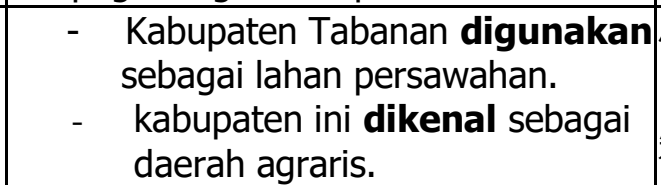 & $\begin{array}{l}\text { 使用される shiyousareru } \\
\text { 知られている shirareteiru }\end{array}$ \\
\hline 11 & ...hak yang sudah dicuri & 盗まれたnusumareta \\
\hline 12 & ...Si Pitung tidak disukai & 嫌がれたiyagareta \\
\hline 13 & ....hasil rampasan itu diberikan & 与えられたataerareta \\
\hline 14 & ...ilmu yang diajarkan & $\begin{array}{l}\text { 教えられた oshierareta/ } \\
\text { 教えてもらつたoshietemoratta } \\
\text { (bisa dalam bentuk pasif maupun benefaktif) }\end{array}$ \\
\hline
\end{tabular}

Tabel 2: Data Bentuk Pasif Bahasa Jepang

\begin{tabular}{|c|l|l|}
\hline $\begin{array}{c}\text { Data } \\
\text { No. }\end{array}$ & \multicolumn{1}{|c|}{ Kalimat Pasif } & Ekspresi dalam bahasa Jepang \\
\hline 1 & まわりの人にいわれる mawari hito ni iwareru & dikatakan \\
\hline 2 & 思われません omowaremasen & tidak terpikirkan \\
\hline 3 & 切られた kirareta & dipotong \\
\hline 4 & 足をとられてashi wo torarete & kaki disandung \\
\hline 5 & きりひらかれていました kirihirakareteimashita & terpotong seluruhnya \\
\hline 6 & 賓乏神に教えられた binbougami ni oshierareta & diajarkan \\
\hline 7 & 見むきもされないmimukimosarenai & diabaikan \\
\hline
\end{tabular}

\section{SIMPULAN}

Dari hasil analisis, didapatkan simpulan tentang padanan kalimat pasif bahasa Indonesia dan bahasa Jepang.

1. Tidak semua kalimat pasif Indonesia dapat diungkapkan kembali dalam bentuk pasif dalam bahasa Jepang. Dalam bahasa Jepang misalnya untuk pasif yang ditandai oleh prefiks ter- seperti tertidur atau ter- peleset tidak dapat diungkapkan dalam rareru dalam bahasa Jepang karena akan mengubah maknanya. Untuk tertidur, dapat menggunakan struktur - te shimau sehingga menjadi neteshimatta sedangkan untuk terpeleset menggunakan bentuk kausatif seru/saseru sehingga menjadi subaraseta. Kalimat pasif bahasa Indonesia 
Sri Iriantini, Vina Febriani, Toni Heryadi: Kesalahan Penganalisisan Kalimat Pasif dari...

dengan verba tertidur, terpeleset, terletak akan menghasilkan kalimat pasif bahasa Jepang karena verba kalimanya adalah verba statis dan perbuatanya tidak disengaja.

2. Kalimat pasif dengan verba dibeli, dibaca, dimatikan, jika diterjemahkan ke dalam bahasa Jepang, akan menghasilkan kalimat aktif dalam bahasa Jepang. Verba membeli kau, membaca yomu, dan mematikan kesu. Sementara untuk verba yang mengandung ekspresi terima kasih atau ada peruntung dalam kalimat tersebut, digunakan verba benefaktif dalam bahasa Jepang yang terdiri dari 7 varian, yaitu yaru, ageru, kureru, sashiageru, kudasaru, morau, dan itadaku. Contohnya pada data dibersihkan menjadi soujishitekureta. Kalimat pasif bahasa Indonesia dengan

\section{DAFTAR PUSTAKA}

Alwi, Hasan dkk. 1998. Tata Bahasa Baku Bahasa Indonesia. Jakarta: Balai Pustaka.

Chaer, Abdul. 2003. Linguistik Umum. Jakarta: Rineka Cipta

Djajasudarma, T.Fatimah. 2003. Analisis Bahasa Sintaksis dan Semantik. Bandung: Uvula Press Fakultas Sastra Universitas Padjadjaran.

Djajasudarma, T.Fatimah, 2010. Metode Linguistik, Ancangan Metode Penelitian dan Kajian. Bandung: PT. Refika Aditama.

Iori, Isao, et.al. 2001 Chuujoukyuu o Oshieruhito no tame no Nihongo Bunpou Handobukku. Tokyo: 3A Corporation.

Itou, Hiromi. 2010. Jujukoubun ni okeru Jueki to Onkei oyobi Teineisa. -

[tekureru] bun to [temorau] bun o chuushin ni. Nihongo Gakuronshuu, dai 6 gou.

Heryadi, Toni. 1999. "Perbandingan Kalimat Pasif Berprefiks di- dan Te(R)- verba dibeli, dibaca, dimatikan, apabila diterjemahkan ke dalam bahasa Jepang, akan berubah menjadi kalimat aktif dalam bahasa Jepang. Hal ini terjadi karena makna inhern pada verba tersebut. Verba dibeli, dibaca, dan dimatikan termasuk verba dinamis, yaitu berupa verba aktivitas atau perbuatan yang tidak disengaja. Untuk bentuk pasif diajarkan, dalam bahasa Jepang dapat diungkapkan dengan dua bentuk yaitu oshierareta atau dengan bentuk benefaktif menjadi oshietemoratta. Prefiks di- yang merupakan salah satu penanda pasif dalam bahasa Indonesia jika diungkapkan ke dalam bahasa Jepang tidak selalu bisa dipadankan dengan bentuk pasif reru/rareru sehingga hal ini menjadi kendala bagi pembelajar bahasa Jepang yang berbahasa ibu bahasa Indonesia.

dalam Bahasa Indonesia. Skripsi.

Bandung: Universitas Padjadjaran.

Dewi, T. F., Nimashita, H., \& Isnaini, Z. L. 2017. Into Japanese Language (Study on Laskar Pelangi and Niji no Shounen Tachi Novel) (Studi Pada Novel Laskar Pelangi Dan Niji No Shounen Tachi). Jurnal Online Mahasiswa Fakultas Keguruan Dan IImu Pendidikan Universitas Riau, 21(2), 1-12. Retrieved from https://media.neliti.com/media/publicat ions/201641-none.pdf

Desilawati, E., \& Kasnaria, M. 2018. Kemampuan Membuat Kalimat Pasif Siswa Kelas Xi Jurusan Teknik Jaringan Tenaga Listrik Smk Negeri 2 Pekanbaru. JURNAL PAJAR (Pendidikan Dan Pengajaran), 2(4), 593. https://doi.org/10.33578/pjr.v2i4.5709

Novikasari, I. 2016. Kesalahan penggunaan kalimat pasif bahasa jepang pada mahasiswa sastra jepang universitas diponegoro. Skripsi. Retrieved from http://eprints.undip.ac.id/50030/

Puspa, I. A. W. 2014. Perubahan struktur aktif ke pasif kalimat bahasa jepang. Skripsi, 1-10. Retrieved from http://eprints.undip.ac.id/45411/1/JUR NAL.pdf 
Sri Iriantini, Vina Febriani, Toni Heryadi: Kesalahan Penganalisisan Kalimat Pasif dari...

Saidi, S. M. 2016. Fungsi Pelaku Dalam Kalimat Pasif Bahasa Indonesia. Paramasastra, 3(2), 208--223. https://doi.org/10.26740/parama.v3i2. 1526

Sutedi, D. 2004. Masalah Kalimat Pasif dalam Bahasa Jepang. Fokus, 1(2), 1023.

Sutedi, D. 2013. Berdasarkan Kategori Dan Peran Semantisnya. Journal Humanio$r a, 25(3), 343-355$. Retrieved from https://pdfs.semanticscholar.org/fc42/2 538d43364c9c6ada5983d1305d39b0a1 41f.pdf

Sutedi, D. 2016. Contrastive Analysis of Japanese and Indonesian Passive Sentences. Mediterranean Journal of Social Sciences, 71), 317-326.

https://doi.org/10.5901/mjss.2016.v7n 1s1p317

Sutedi, D. 2013. Berdasarkan Kategori Dan Peran Semantisnya, 25(3), 343-355. Retrieved from https://pdfs.semanticscholar.org/fc42/2 538d433364c9c6ada5983d1305d39b0a1 41f.pdf

Sutedi, D. 2016. Contrastive Analysis of Japanese and Indonesian Passive Sentences. Mediterranean Journal of Social Sciences, 7(1), 317-326. https://doi.org/10.5901/mjss.2016.v7n 1s1p317

Purwo, Bambang Kaswanti. 1989. SerpihSerpih Telaah Pasif Bahasa Indonesia.

Sunagawa, Yuriko et al. 2002. Nihongo Bunkei Jiten. Tokyo: Kuroshio

Koizumi, Tamotsu. 2007. Gengogaku Nyuumon. Tokyo : Taishuukan Shoten.

Kuno, Susumu. 1973. The Structure of the Japanese Language. Cambridge: The MIT Press

Sudaryanto. 1992. Metode Linguistik, ke Arah Memahami Metode Linguistik.
Yogyakarta: Gadjah Mada University Press.

Takami, Kenichi. 2011 Ukemi to Shieki, Sono Imi Kisoku o Saguru. Tokyo: Kaitakusha.

Torita, Kazumi. 2009. Juju Doushi [yaru/kureru/morau] Bun no Imi Bunseki- Chuushouteki Taishoubutsu o Fukumu Jujudoushi Bun o Chuushin ni-. Gengogakurongyou, online han dai 2 gou.

Tsujimura, Natsuko. 1996. An Introduction to Japanese Linguistics. United Kingdom: Blackwell Publishing. 